\title{
Agricultural practices that reduce greenhouse gases (GHGs) and generate co-benefits
}

\author{
K. Duncan \\ Health Studies, University of Toronto at Scarborough, Canada
}

\begin{abstract}
Human activities are increasing atmospheric greenhouse gas concentrations, and increasing temperature. The atmospheric concentration of carbon dioxide $\left(\mathrm{CO}_{2}\right)$ increased from a pre-industrial level of $280 \mathrm{ppm}$ to $379 \mathrm{ppm}$ in 2005, methane $\left(\mathrm{CH}_{4}\right)$ increased form $715 \mathrm{ppb}$ to $1774 \mathrm{ppb}$, and nitrous oxide $\left(\mathrm{N}_{2} \mathrm{O}\right)$ increased from $270 \mathrm{ppb}$ to $319 \mathrm{ppb}$, and globally averaged surface temperatures increased $0.6+0.2^{\circ} \mathrm{C}$ over the $20^{\text {th }}$ century (Alley 2007 Climate Change 2007: the Physical Science Basis. Summary for Policymakers. In IPCC Fourth Assessment Report, pp. 1-18).

Stabilizing atmospheric GHG concentrations will require effort in every sector of the economy, including agriculture, forestry, manufacturing, minerals, and oil and gas. Agriculture, however, has a particularly important role to play in terms of carbon sequestration (Pew Center on Global Climate Change 1999 Agriculture's role in addressing climate change. http://www.pewclimate.org/ policy_center/policy_reports_and_analysis/brief_agricultures. February 8, 2005; and McNaughton 2001 A Workbook on Greenhouse Gas Mitigation for Agricultural Managers. Alberta Environmental Sustainable Agriculture). Agricultural practices that offset or reduce GHGs (e.g. store carbon in plants and soil, or decrease methane and nitrous oxide emissions from agricultural lands and livestock) may also have a positive impact on the quality of air, soil, water, wildlife habitats, and indeed the broader environment (U.S. Environmental Protection Agency 2004 Environmental co-benefits of sequestration practices. http://www.epa.gov/sequestration/co-benefits.html. March 1, 2005).

This paper therefore identifies agricultural practices that reduce GHGs and generate environmental and economic co-benefits.

Keywords: climate change, agriculture, greenhouse gas reductions, economic and environmental co-benefits.
\end{abstract}




\section{Introduction}

In light of the necessity to reduce agricultural gas emissions and the economic and environmental prospects for producers, this paper aims to elucidate the opportunities for GHG reductions and co-benefits. Specifically, this paper seeks to determine the reduction and co-benefit opportunities associated with the following agricultural practices: animal management; conservation tillage; crop management; fertilizer management; manure management; reduced fossil fuel use; shelterbelts; and soil and water management.

Following a thorough review of the literature, the author developed Table 1 showing the associated GHG reductions and the major co-benefits for the above agricultural practices; only those benefits listed in the literature were included. Because all practices have drawbacks (and these vary for the operation and location of the farm), only major disadvantages are presented. It is recognized that the table is far from exhaustive, but rather highlights major agricultural practices, the numerous opportunities for GHG reductions and co-benefits across a range of sub-sectors.

\section{Conclusions}

Based on the analysis in Table 1, it might be useful for producers to consider a GHG activity portfolio at different timescales - in the near term and in the long term. Some practices might be undertaken in short order, and at very little cost with multiple benefits: for example, improved soil management practices or crop rotation on forest soils. Over the longer term, farmers might employ low-cost changes in crop and livestock practices.

For many producers, these low-cost, climate-friendly practices may make good financial sense. Other farmers may, however, find that climate-friendly practices (particularly high-cost practices, such as afforestation or biofuels) do not make financial sense, and would therefore increase such practices only if financial inducements were available. Farmers might adopt new practices if payments were large enough to cover direct costs (e.g. the cost of new equipment, loss in profits caused by crop switching, etc.) and indirect costs (e.g. six years may be needed to successfully switch from conventional tillage to notill) (Pew Center on Global Climate Change 1999). 
Environmental Toxicology II 63

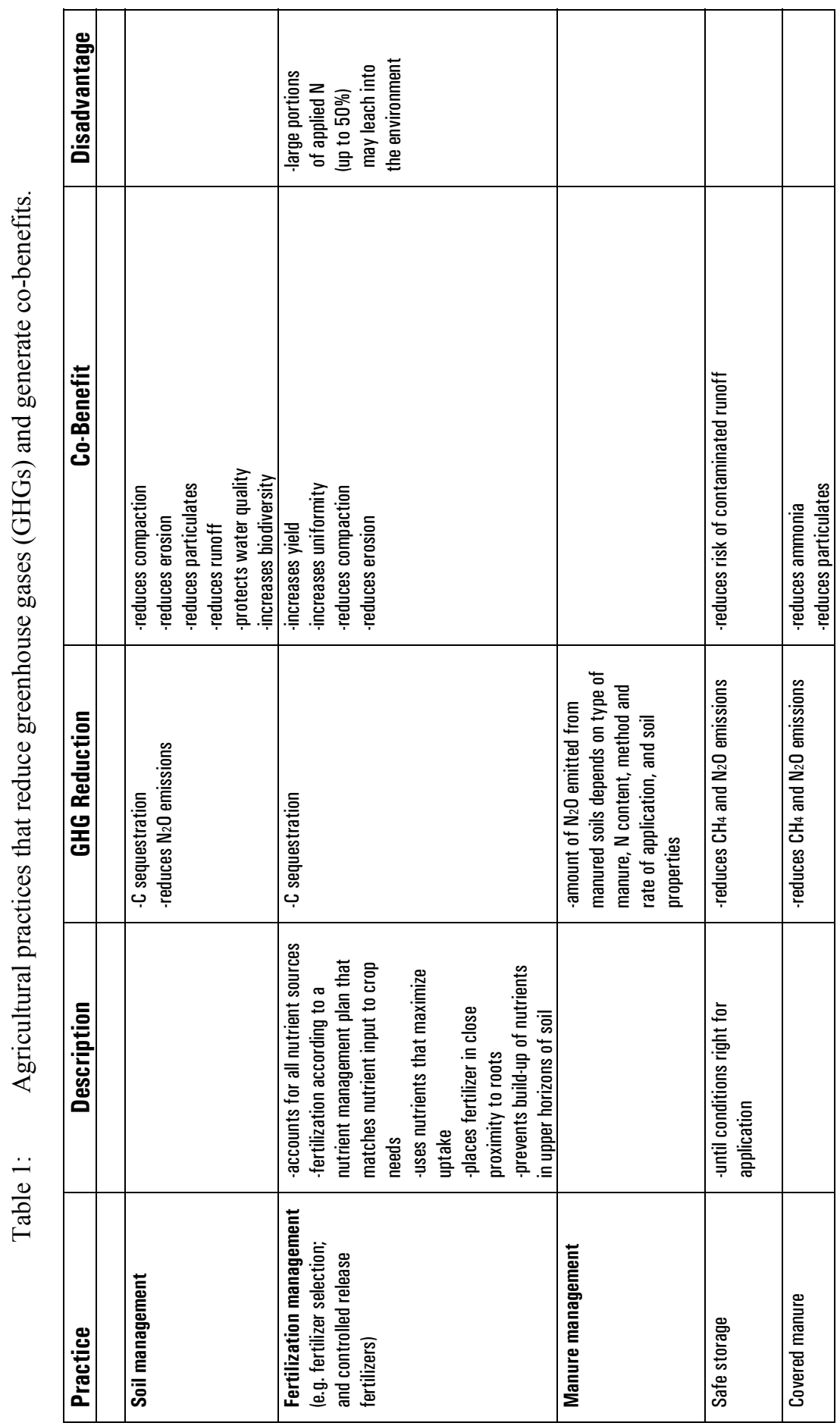

WIT Transactions on Ecology and the Environment, Vol 110, (C) 2008 WIT Press www.witpress.com, ISSN 1743-3541 (on-line) 


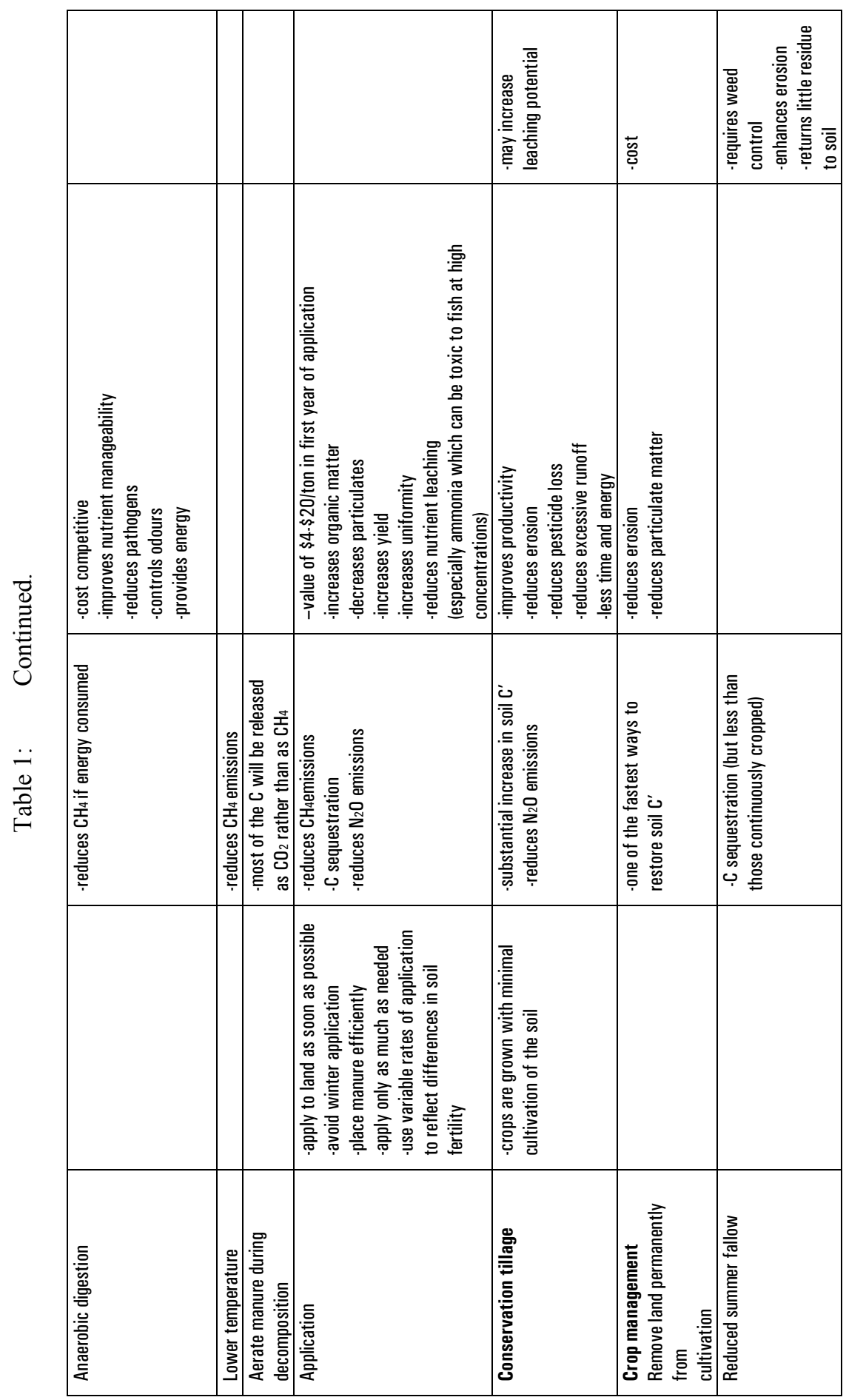

WIT Transactions on Ecology and the Environment, Vol 110, (C) 2008 WIT Press www.witpress.com, ISSN 1743-3541 (on-line) 


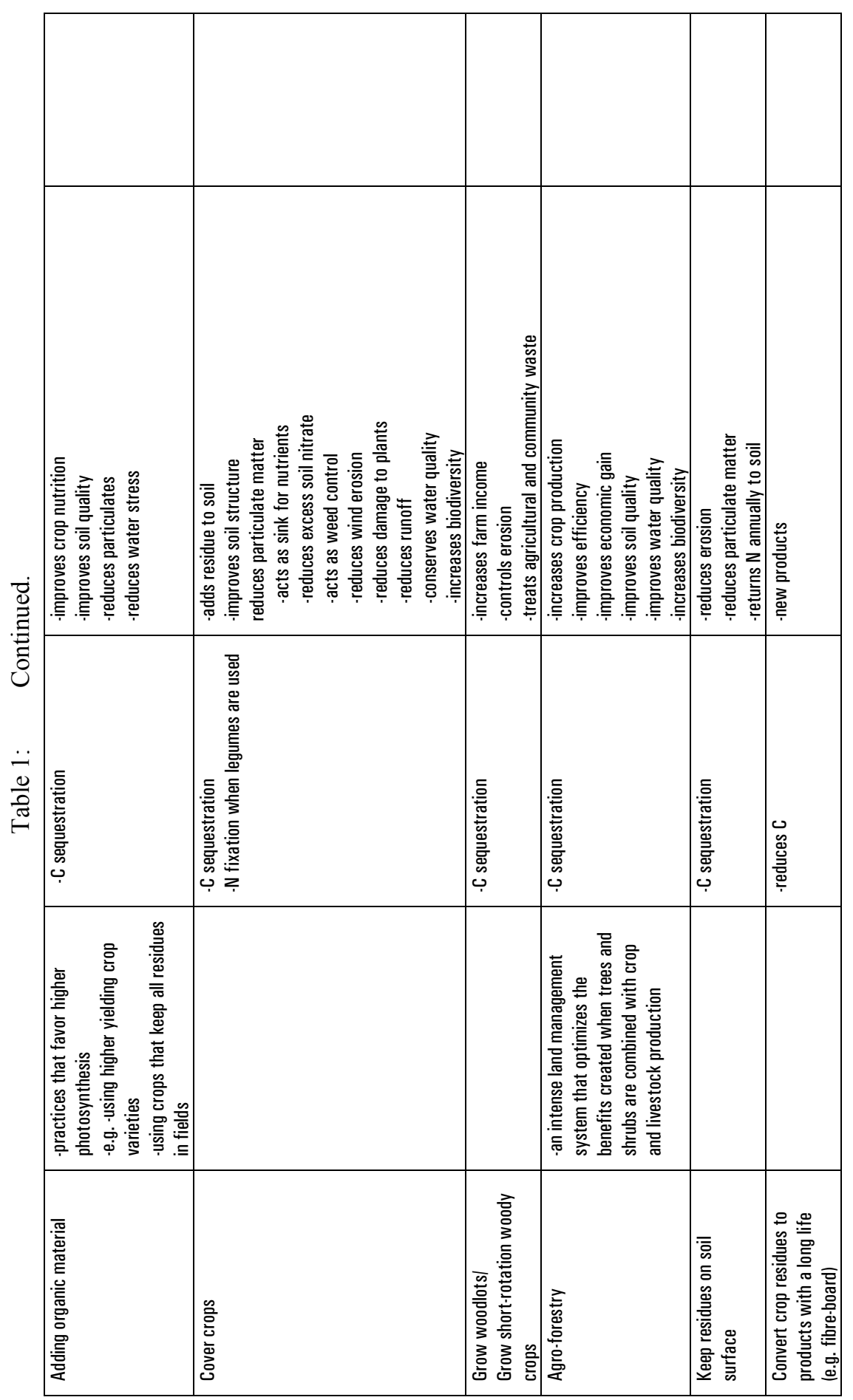

WIT Transactions on Ecology and the Environment, Vol 110, (C) 2008 WIT Press www.witpress.com, ISSN 1743-3541 (on-line) 


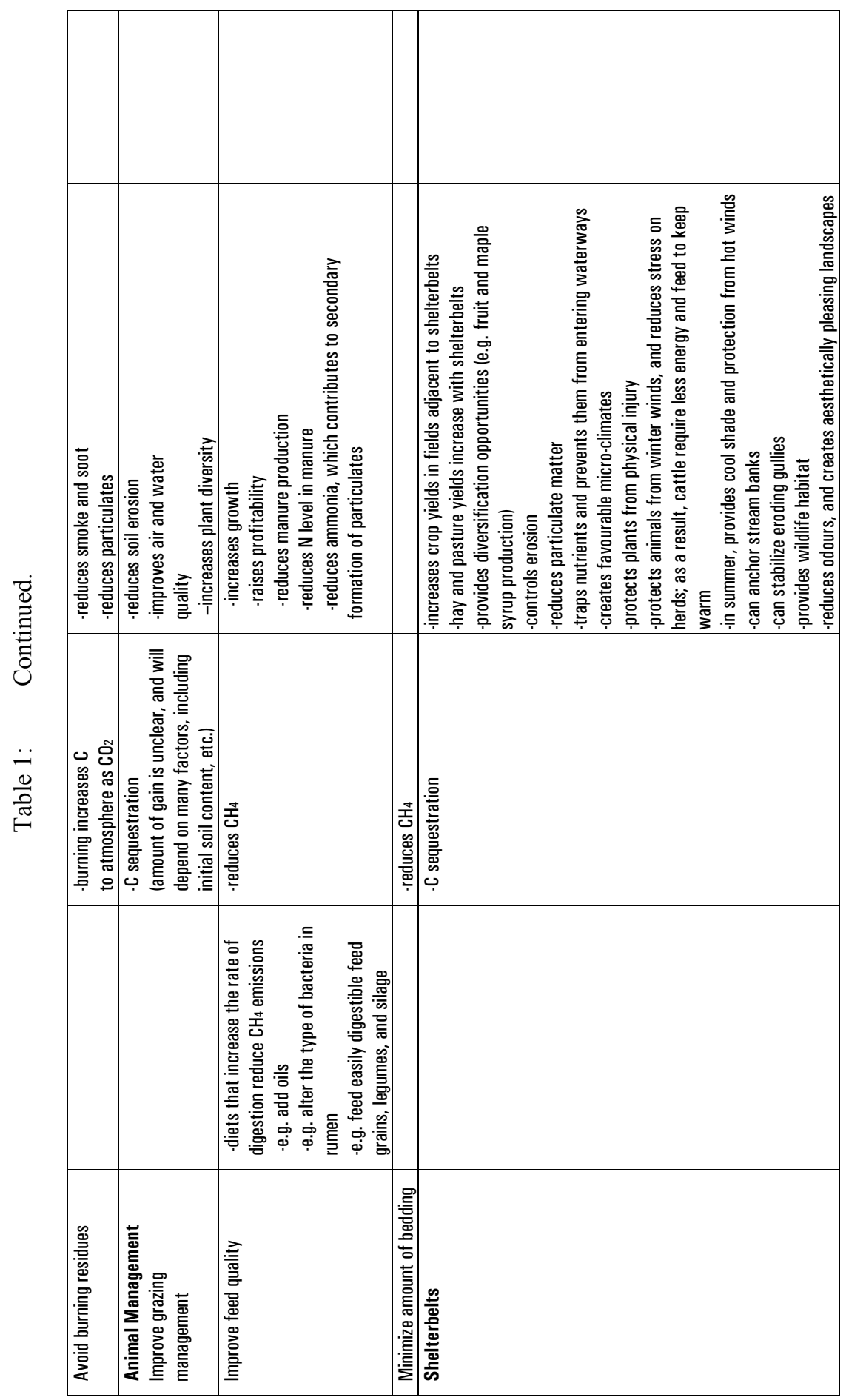

WIT Transactions on Ecology and the Environment, Vol 110, (C) 2008 WIT Press www.witpress.com, ISSN 1743-3541 (on-line) 
Environmental Toxicology II 67

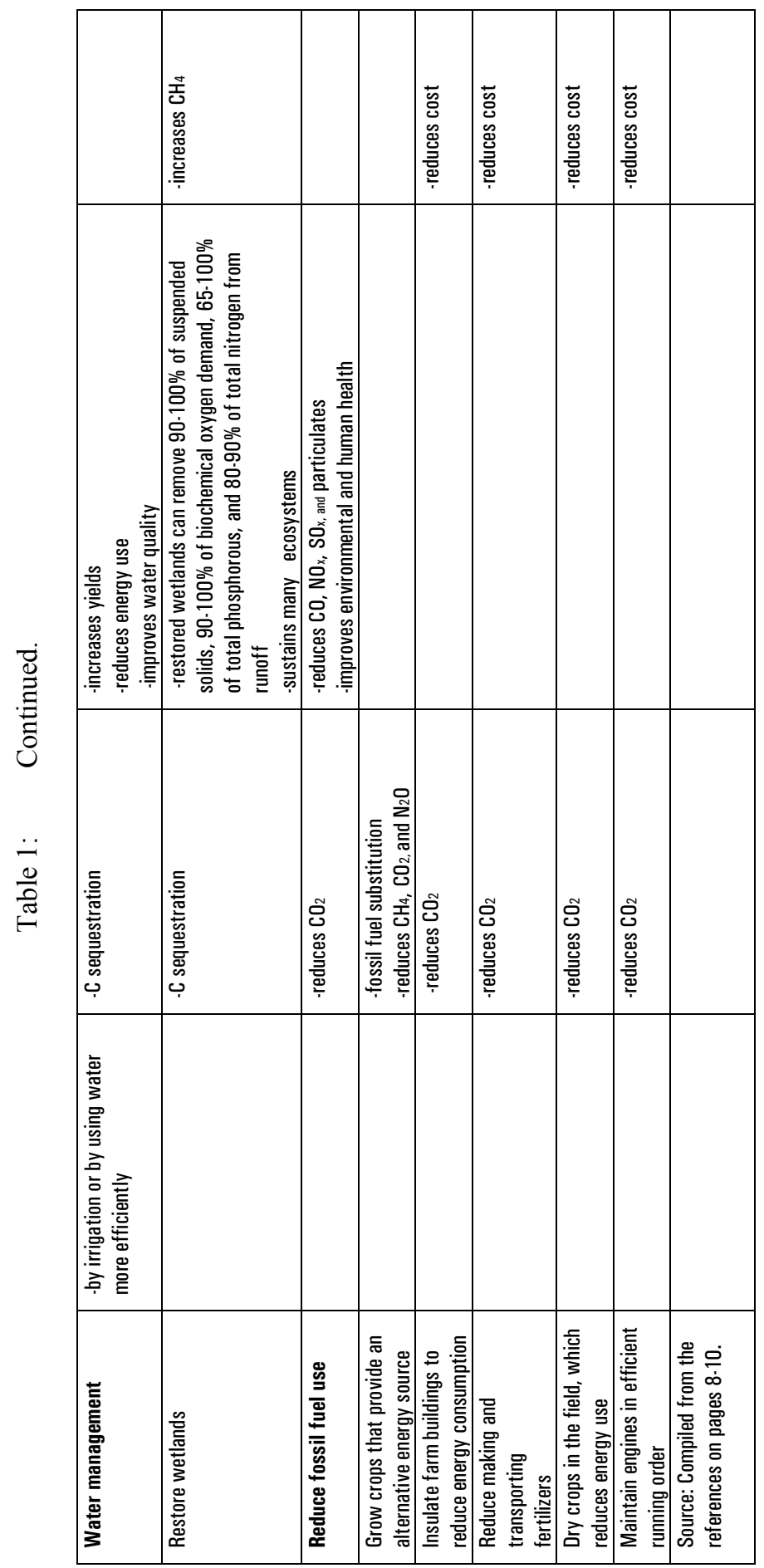

WIT Transactions on Ecology and the Environment, Vol 110, (C) 2008 WIT Press www.witpress.com, ISSN 1743-3541 (on-line) 


\section{References}

[1] Agriculture and Agri-Food Canada. 2000. Reducing Greenhouse Gas Emissions from Canadian Agriculture. Agriculture and Agri-Food Climate Change Table. Publication \# 2028/E.

[2] Agriculture and Agri-Food Canada. 2003. a. Agriculture as a solution to pollution. http://www.agr.gc.ca/pfra/climate/solution_e.htm. February 8 , 2005.

[3] Agriculture and Agri-Food Canada. 2003. b. Agroforestry-a sink for carbon. http://www.agr.gc.ca/pfra/climate/carbon_e.htm. February 8, 2005.

[4] Agriculture and Agri-Food Canada. 2003. c. Beneficial management practices which may reduce greenhouse gases (GHGs). http://www.agr.gc.ca/pfra/climate/practices_e.htm. February 8, 2005.

[5] Agriculture and Agri-Food Canada. 2003. d. Beneficial practices, which improve water quality. http://www.agr.gc.ca/pfra/water/practices_e.htm. February 8, 2005.

[6] Agriculture and Agri-Food Canada. 2003. e. Energy savings and farmyard shelterbelts. http://www.agr.gc.ca/pfra/climate/energy_e.htm. February 8 , 2005.

[7] Agriculture and Agri-Food Canada. 2003. f. Tree planting benefits wildlife and the environment. http://www.agr.gc.ca/pfra/climate/wildplant_ehtm. February 8, 2005.

[8] Alley, R. 2007. Climate Change 2007: the Physical Science Basis. Summary for Policymakers. In IPCC Fourth Assessment Report, pp. 1-18.

[9] American Farmland Trust. nd. Carbon sequestration: a win-win strategy for America's farmers. http://www.farmland.org/policy/issues_carbon.htm. February 20, 2005.

[10] Boehm, M. nd. Kyoto protocol and agriculture. http://www.mandakzerotill. org/book25/06_Marie\%20Boehm\%20Presentation.htm. February 8, 2005.

[11] Greenlaugh, S. and Sauer, A. 2003. Awakening the Dead Zone: An Investment for Agriculture, Water Quality, and Climate Change.' Issue Brief, World Resources Institute, Washington, DC.

[12] Intergovernmental Panel on Climate Change. 2001. Climate Change 2001: The Scientific Basis. Contribution of Working Group $l$ to the Third Assessment Report of the Intergovernmental Panel on Climate Change (IPCC). Cambridge University Press: Cambridge.

[13] Intergovernmental Panel on Climate Change. 2001. Climate Change 2001: Impacts, Adaptation, and Vulnerability. Contribution of Working Group ll to the Third Assessment Report of the Intergovernmental Panel on Climate Change (IPCC). Cambridge University Press: Cambridge.

[14] McCarl, B. 1995. Curbing greenhouse gases: agriculture's role. http://www.agecon.tamu.edu/people/faculty/mccarl_bruce/papers/728.pdf. February 10, 2005.

[15] McNaughton, N. 2001. A Workbook on Greenhouse Gas Mitigation for Agricultural Managers. Alberta Environmental Sustainable Agriculture. 
[16] Ministry of Agriculture and Food. 2004. a. Best management practices series. $\quad \mathrm{http} / / \mathrm{www}$.gov.on.ca/OMAFRA/english/environment/bmp/ series.htm. March 15, 2005.

[17] Pew Center on Global Climate Change. 1999. Agriculture's role in addressing climate change. http://www.pewclimate.org/policy_center/ policy_reports_and_analysis/brief_agricultures. February 8, 2005.

[18] U.S. Environmental Protection Agency. 2004. a. Environmental co-benefits of sequestration practices. http://www.epa.gov/sequestration/cobenefits.html. March 1, 2005. 